Original Paper

\title{
Peningkatan Kinerja Guru Kimia dalam Melaksanakan Pembelajaran Yang Efektif Melalui Supervisi Klinis Upaya Meningkatkan Mutu Di SMA Lombok Tengah
}

\author{
Bambang Nurcahyono ${ }^{1^{*}}$ \\ ${ }^{1}$ Dinas Pendidikan dan Kebudayaan UPTD. Layanan Dikmen \& PK-PLK Lombok Tengah.
}

*Corresponding Author:

Bambang Nurcahyono, Dinas

Pendidikan dan Kebudayaan

UPTD. Layanan Dikmen \& PK-

PLK Lombok Tengah, Indonesia;

Email:

nurcahyonobambang4@gmail.com

\begin{abstract}
Abstrak: Tujuan dari penelitian ini adalah untuk mengetahui kinerja guru dalam melaksanakan pembelajaran yang efektif melalui supervisi klinis dalam upaya peningkatan mutu SMA di Lombok Tengah tahun pelajaran 2018-2019. Jenis penelitian ini adalah merupakan penelitian tindakan kepengawasan (PTKp) yang dilaksanakan dalam 3 siklus. Penelitian dilakukan di 18 SMA Negeri Kabupaten Lombok Tengah dalam bulan Agustus 2018 sampai dengan bulan Oktober 2018 pada semester ganjil tahun pelajaran 2018-2019. Subjek penelitian ini adalah guru binaan mata pelajaran kimia sebanyak 32 orang yang tersebar di SMA Lombok Tengah. Teknik pengumpulan data yang digunakan adalah observasi dan angket. Data yang terkumpul dianalisis secara kuantitatif untuk menghitung besarnya peningkatan kompetensi guru dalam melaksanakan pembelajaran yang efektif di sekolah dan kualitatif untuk memberikan gambaran hasil penelitian secara reduksi data, sajian deskriptif dan penarikan kesimpulan. Hasil penelitian ialah terjadi peningkatan Kompetensi setelah diberi pembinaan melalui Supervisi klinis yaitu (1) Dari sebelum pembinaan (Siklus I) dan setelah pembinaan oleh pengawas sampai dengan (Siklus II) 70,00\% menjadi 77,44\%.; (2) Dari Pembinaan pada Siklus II dan setelah pembinaan melalui Supervisi klinis (Siklus III) $77,44 \%$ menjadi $82,44 \%$; (3) Rata-rata kinerja guru sebelum diberi pembinaan 40,63\% naik menjadi $100 \%$; (4) Pembinaan Pengawas dalam upaya meningkatkan kinerja guru-guru binaan mata pelajaran kimia dalam melaksanakan Pembelajaran Yang Efektif melalui Supervisi klinis menunjukan peningkatan pada setiap siklus; (5) Aktivitas dalam kegiatan pembinaan bahwa guru-guru binaan mata pelajaran kimia dapat meningkatkan kinerja pada proses pelaksanaan Pembelajaran Yang Efektif dengan baik dalam setiap aspek; (6) Peningkatan kinerja guru dalam melaksanakan peran dan fungsinya menunjukkan bahwa kegiatan pembinaan Supervisi klinis bermanfaat dan dapat membantu guru untuk lebih mudah memahami konsep peran dan fungsi guru sehingga kinerja guru dapat meningkat.
\end{abstract}

Kata Kunci: Peningkatan Kinerja Guru, Pembelajaran Efektif, Supevisi Klinis

\section{Pendahuluan}

Kompetensi para guru merupakan salah satu faktor yang dapat mempengaruhi keberhasilan pembelajaran. Guru yang memiliki kompetensi tinggi akan mencoba dan mencoba menerapkan berbagai penemuan baru yang dianggap lebih baik untuk pembelajaran siswa di sekolah. Proses pembelajaran merupakan kegiatan inti dari keseluruhan proses pendidikan di sekolah.
Kemampuan guru dalam melaksanakan pembelajaran dengan baik di kelas sangat berpengaruh terhadap keberhasilan pencapaian tujuan pendidikan secara maksimal yang dapat dicapai oleh siswa, oleh karena itu peranan pengawas sekolah dalam membimbing guru di sekolah yang menjadi tanggung jawabnya sudah menjadi kewajiban yang harus dilakukan bagi seorang pengawas sekolah sebagai upaya peningkatan mutu pendidikan di sekolah.

Keberhasilan dalam pencapaian peningkatan mutu pendidikan merupakan perioritas utama dalam 
menyelenggarakan pendidikan nasional. Untuk meningkatkan mutu pendidikan,pemerintah melalui Dinas Pendidikan dan Kebudayaan telah melakukan berbagai upaya di antaranya; (1) Perubahan Undang undang sistem pendidikan, (2) Peningkatan kualifikasi dan profesionalisme guru, (3) Peningkatan kesejahteraan guru, (4) Pembaharuan kurikulum, (5) Peningkatan anggaran pendidikan, (6) Pengembangan sarana dan prasarana pendidikan. Di samping itu untuk pendidikan kejuruan diselenggarakan sistem magang ke dunia kerja, yang dikenal dengan pendidikan sistem ganda baik di lingkup lokal, maupun nasional.

Berbagai upaya yang telah dilakukan untuk meningkatkan capai mutu pendidikan melalui penyelenggaraan pendidikan yang ada bisa menghasilkan sumber daya manusia yang berkualitas. Sumber daya manusia dikatakan berkualitas bilamana mereka mampu mandiri. Kemandirian yang diharapkan ada dua hal yaitu: (1) Mandiri selama masih menempuh pendidikan,yaitu dalam mencapai prestasi belajarnya. Tolak ukur prestasi belajar ini tidak saja terlihat dari nilai klinis yang telah dicapai, tetapi juga dari bagaimana proses untuk mencapai nilai klinisnya. ( 2 ) Mandiri setelah lulus dari jenjang yang ditempuhnya. Tolak ukurnya antara lain; (a) mampu mengaktualisasikan diri dan mengembangkan bakat atau Kompetensinya, (b) sebagai warga negara mereka mampu hidup bersama keluarga, golongan, masyarakat, suku bangsa dan bilamana perlu dengan masyarakat global, dan (c) sebagai tenaga kerja yang mampu mengontrol lingkup pisiknya untuk meningkatkan taraf hidupnya.

Peranan guru dalam proses pembelajaran dalam upaya peningkatan capaian mutu pendidikan sangat menentukan bagi kualitas hasil yang dicapai oleh siswa. Dalam pelaksanaan fungsi dan tugasnya, guru sebagai profesi yang menyandang persyaratan tertentu sesuai yang tertuang dalam UU SISDIKNAS Nomor 20 Tahun 2003 pasal 39 (1) dan (2). Dari tugas dan tanggungjawab yang diemban, guru dituntut untuk memiliki beberapa kemampuan dan keterampilan tertentu yang dimana kemampuan dan keterampilan tersebut merupakan bagian dari kompetensi profesionalisme guru untuk dapat melaksanakan tugas dan tanggung jawabnya dengan baik. Sesuai dengan yang diungkapkan oleh Danim (2002) bahwa guru bermakna sebagai pendidik profesional dengan tugas utama mendidik, mengajar, membimbing, mengarahkan, melatih, menilai dan mengevaluasi peserta didik pada jalur Pendidikan formal. Ketika guru sebagai tenaga pendidik mampu secara profesional melaksanakan pembelajaran di kelas maka akan memberikan kontribusi yang positif bagi prestasi akademik siswanya.

Tugas dan tanggung jawab guru sebagai tenaga pendidik sangat erat kaitannya dengan usaha peningkatan kualitas sumber daya manusia di sektor pendidikan. Oleh karena itu, perlu upayaupaya dalam meningkatkan mutu guru untuk menjadi tenaga pendidik yang profesional agar dapat meningkat seperti yang dikemukakan oleh Tilaar (2002) bahwa untuk menjadikan guru sebagai tenaga pendidik yang profesional maka perlu adanya pembinaan secara terus menerus dan berkesinambungan. Memberikan penataran, pelatihan dan memberikan kesempatan untuk belajar lagi belum cukup untuk menjadikan guru menjadi tenaga yang profesional, tetapi juga memerhatikan guru dari segi peningkatan disiplin, pemberian motivasi, dan pemberian bimbingan melalui supervisi. Pembinaan secara berkelanjutan oleh pengawas sekolah terhadap guru perlu dilakukan terutama kepada mereka yang belum menyelesaikan pendidikan keguruannya sampai ketingkat sarjana (S-1).

Banyak di lapangan ditemukan secara factual guru-guru yang mengampu mata pelajaran kimia di SMA Lombok Tengah mengalami kesulitan dalam melaksanakan pembelajaran yang efektif, sehingga pengawas pembina perlu melakukan pembinaan untuk upaya meningkatkan kompetensinya dalam melaksanakan pembelajaran yang efektif.

Berbantuan penerapan supervis klinis pengawas pembina mata pelajaran melakukan pembinaan, berdasarkan latar belakang di atas penulis melakukan penelitian dengan judul: Peningkatan Kinerja Guru Kimia dalam Melaksanakan Pembelajaran yang Efektif melalui Supervisi Klinis Upaya Meningkatkan Mutu di SMA Lombok Tengah Tahun Pelajaran 2018-2019.

Menurut Jerry (2013) supervisi klinis adalah supervisi yang difokuskan pada perbaikan pembelajaran melalui siklus yang sistematis mulai dari tahap perencanaan, pengamatan dan analisis yang intensif terhadap pembelajarannya dengan tujuan untuk memperbaiki proses pembelajaran. Hal ini sejalan dengan pendapat yang diungkapkan oleh Arikunto (2004) bahwa kegiatan pokok supervisi adalah melakukan pembinaan kepada 
sekolah pada umumnya dan guru pada khususnya agar kualitas pembelajaran meningkat. Sebagai dampak meningkatnya kualitas pembelajaran, tentu dapat meningkatkan pula prestasi belajar siswa, dan itu berarti meningkatkan kualitas lulusan sekolah itu. Hasil penelitian yang dilakukan oleh Amani, dkk (2013) menyatakan bahwa implementasi supervisi klinis mampu meningkatkan kemampuan guru dalam mengelola proses pembelajaran.

Tujuan penelitian ini adalah untuk: 1) Mengetahui kinerja guru dalam melaksanakan pembelajaran yang efektif melalui supervisi klinis upaya meningkatkan mutu di SMA Lombok Tengah tahun pelajaran 2018-2019. 2) Mengetahui efektivitas pembinaan pengawas melalui supervisi klinis meningkatkan kinerja guru kimia dalam melaksanakan pembelajaran yang efektif di SMA Lombok Tengah tahun pelajaran 2018-2019. Manfaat penelitian ini adalah sebagai berikut: 1) Hasil penelitian ini dapat dijadikan refleksi terhadap program pembinaan guru melalui supervisi klinis sehingga dapat diadakan revisi terhadap kegiatan yang telah dilakukan. 2) Hasil penelitian ini diharapkan dapat digunakan sebagai bahan pertimbangan dalam melakukan pengembangan model supervisi bagi para guru di sekolah pada umumnya dan khususnya di SMA. 3) Hasil penelitian ini dapat dijadikan referensi bagi penelitian berikutnya.

\section{Metode}

Penelitian ini merupakan penelitian kualitatif dengan pendekatan Penelitian Tindakan Sekolah yang dilakukan oleh pengawas sekolah sebagai peneliti. Dalam penelitian ini sebagai subjeknya adalah guru-guru kimia di SMA Lombok Tengah yang menjadi Binaan peneliti tahun pelajaran 20182019. Setting penelitian ini adalah: 1) PTKp dilakukan pada guru binaan mata pelajaran kimia di SMA Lombok Tengah tahun pelajaran 2018-2019. 2) Guru mata pelajaran kimia yang menjadi guru binaan terdiri dari 32 orang guru yang tersebar di SMA Lombok Tengah.

Rancangan Penelitian ini adalah: 1) Tindakan dilaksanakan dalam 3 siklus, meliputi: perencanaan, tindakan, pengamatan, refleksi. 2) Kegiatan dilaksanakan dalam semester ganjil tahun pelajaran 2018-2019. 3) Lama penelitian PTKp dilaksanakan mulai tanggal 20 Agustus s.d 22 Oktober 2018.
Rancangan Penelitian Tindakan Kepengawasan (PTKp ) menurut Kemmis dan Taggart (1992) dapat dilihat pada Gambar 1.

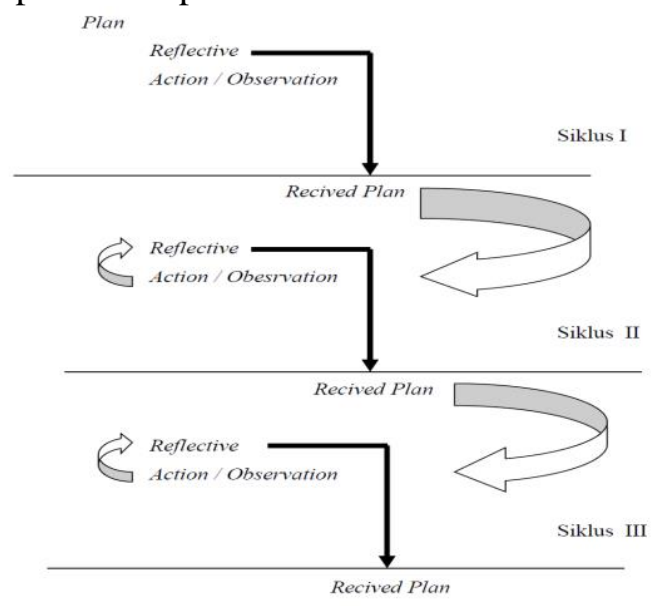

Gambar 1. Rancangan Penelitian Tindakan Kepengawasan

Penjelasan rancangan penelitian tindakan kepengawasan pada Gambar 1 adalah: 1) Rencana (Plan) adalah rencana tindakan apa yang dilakukan untuk memperbaiki, meningkatkan atau perubahan perilaku dan sikap sebagai solusi. 2) Tindakan (Action) adalah apa yang dilakukan oleh peneliti/pengawas sebagai upaya perbaikan, peningkatan atau perubahan yang diinginkan. 3) Observasi (Observation) adalah mengamati atas hasil atau dampak dari tindakan yang dilaksanakan atau dikenakan terhadap guru. 4) Refleksi (reflection) adalah peneliti mengkaji, melihat, dan mempertimbangkan atas hasil atau dampak dari tindakan dari pelbagai keriteria. 5) Revisi (recived plan) adalah berdasarkan dari hasil refleksi ini, peneliti melakukan revisi terhadap rencana awal.

Dalam penelitian tindakan kepengawasan ini variabel yang diteliti adalah peningkatan kinerja guru dalam melaksanakan pembelajaran yang efektif melalui supervisi klinis pengawas upaya meningkatkan mutu di SMA Lombok Tengah tahun pelajaran 2018-2019. Penelitian tindakan kepengawasan yang dilaksanakan dalam tiga siklus dianggap sudah berhasil apabila terjadi peningkatan kinerja guru dalam melaksanakan tugasnya apabila $85 \%$ guru (sekolah yang diteliti) telah mencapai ketuntasan dengan nilai rata rata 75 . Jika peningkatan tersebut dapat dicapai pada tahap siklus 1 dan 2, maka siklus selanjutnya tidak dilaksanakan karena tindakan yang dilakukan sudah dinilai efektif sesuai dengan harapan dalam 
manajemen berbasis sekolah (MBS). Teknik analisis data dalam penelitian ini adalah: 1) Kuantitatif, Analisis ini digunakan untuk menghitung besarnya peningkatan kompetensi guru dalam melaksanakan pembelajaran yang efektif di sekolah dengan menggunakan prosentase (\%). 2) Kualitatif, teknik analisis ini digunakan untuk memberikan gambaran hasil penelitian secara; reduksi data, sajian deskriptif, dan penarikan simpulan.

\section{Hasil dan Pembahasan}

Pelaksanaan tindakan dalam penelitian dilakukan 3 siklus yang terdiri dari tiga kali pertemuan. Waktu yang digunakan setiap kali pertemuan adalah 2 × 60 menit. Pertemuan pertama dilaksanakan pada tanggal 20 Agustus 2018 s.d 03 September 2018 dan pertemuan kedua pada tanggal 06 September 2018 s.d 12 September 2018 dan pertemuan ke tiga 17 September 2018 s.d 24 September 2018. Penelitian tindakan kepengawasan ini dilaksanakan sesuai dengan prosedur rencana pembinaan dan skenario kepengawasan serta surat tugas yang diberikan oleh kepala UPTD. Layanan Dikmen \& PK-PLK Lombok Tengah. Hasil penelitian untuk 3 siklus terdapat pada Tabel 1

Tabel 1. Data Hasil Nilai Tes Pembinaan Pengawas Meningkatkan Kinerja Guru Kimia dalam Melaksanakan Pembelajaran yang Efektif

\begin{tabular}{|c|c|c|c|c|c|c|c|}
\hline \multirow{2}{*}{ No } & \multirow{2}{*}{ Peserta } & \multicolumn{2}{|c|}{ Siklus I } & \multicolumn{2}{|c|}{ Siklus II } & \multicolumn{2}{|c|}{ Siklus III } \\
\hline & & Skor & Keterangan & Skor & Keterangan & Skor & Keterangan \\
\hline 1 & Guru 01 & 80 & Tuntas & 85 & Tuntas & 87 & Tuntas \\
\hline 2 & Guru 02 & 85 & Tuntas & 90 & Tuntas & 95 & Tuntas \\
\hline 3 & Guru 03 & 60 & Tidak Tuntas & 75 & Tuntas & 80 & Tuntas \\
\hline 4 & Guru 04 & 65 & Tidak Tuntas & 70 & Tidak Tuntas & 77 & Tuntas \\
\hline 5 & Guru 05 & 80 & Tuntas & 85 & Tuntas & 86 & Tuntas \\
\hline 6 & Guru 06 & 80 & Tuntas & 84 & Tuntas & 85 & Tuntas \\
\hline 7 & Guru 07 & 85 & Tuntas & 87 & Tuntas & 93 & Tuntas \\
\hline 8 & Guru 08 & 60 & Tidak Tuntas & 65 & Tidak Tuntas & 75 & Tuntas \\
\hline 9 & Guru 09 & 60 & Tidak Tuntas & 65 & Tidak Tuntas & 76 & Tuntas \\
\hline 10 & Guru 10 & 65 & Tidak Tuntas & 77 & Tuntas & 80 & Tuntas \\
\hline 11 & Guru 11 & 85 & Tuntas & 88 & Tuntas & 92 & Tuntas \\
\hline 12 & Guru 12 & 65 & Tidak Tuntas & 80 & Tuntas & 81 & Tuntas \\
\hline 13 & Guru 13 & 75 & Tuntas & 77 & Tuntas & 80 & Tuntas \\
\hline 14 & Guru 14 & 65 & Tidak Tuntas & 70 & Tidak Tuntas & 75 & Tuntas \\
\hline 15 & Guru 15 & 65 & Tidak Tuntas & 77 & Tuntas & 80 & Tuntas \\
\hline 16 & Guru 16 & 75 & Tuntas & 80 & Tuntas & 85 & Tuntas \\
\hline 17 & Guru 17 & 65 & Tidak Tuntas & 71 & Tidak Tuntas & 77 & Tuntas \\
\hline 18 & Guru 18 & 60 & Tidak Tuntas & 81 & Tuntas & 86 & Tuntas \\
\hline 19 & Guru 19 & 65 & Tidak Tuntas & 82 & Tuntas & 86 & Tuntas \\
\hline 20 & Guru 20 & 60 & Tidak Tuntas & 80 & Tuntas & 85 & Tuntas \\
\hline 21 & Guru 21 & 80 & Tuntas & 80 & Tuntas & 85 & Tuntas \\
\hline 22 & Guru 22 & 55 & Tidak Tuntas & 60 & Tidak Tuntas & 75 & Tuntas \\
\hline 23 & Guru 23 & 80 & Tuntas & 85 & Tuntas & 88 & Tuntas \\
\hline 24 & Guru 24 & 55 & Tidak Tuntas & 61 & Tidak Tuntas & 75 & Tuntas \\
\hline 25 & Guru 25 & 60 & Tidak Tuntas & 65 & Tidak Tuntas & 75 & Tuntas \\
\hline 26 & Guru 26 & 60 & Tidak Tuntas & 67 & Tidak Tuntas & 76 & Tuntas \\
\hline 27 & Guru 27 & 70 & Tidak Tuntas & 78 & Tuntas & 80 & Tuntas \\
\hline 28 & Guru 28 & 80 & Tuntas & 85 & Tuntas & 91 & Tuntas \\
\hline 29 & Guru 29 & 80 & Tuntas & 86 & Tuntas & 92 & Tuntas \\
\hline 30 & Guru 30 & 70 & Tidak Tuntas & 80 & Tuntas & 87 & Tuntas \\
\hline 31 & Guru 31 & 80 & Tuntas & 85 & Tuntas & 87 & Tuntas \\
\hline 32 & Guru 32 & 70 & Tidak Tuntas & 77 & Tuntas & 79 & Tuntas \\
\hline \multicolumn{2}{|c|}{ Jumlah } & \multicolumn{2}{|l|}{2240} & \multicolumn{2}{|l|}{2478} & \multicolumn{2}{|l|}{2651} \\
\hline \multicolumn{2}{|c|}{ Skor Maksimum Individu } & \multicolumn{2}{|l|}{100} & \multicolumn{2}{|l|}{100} & \multicolumn{2}{|l|}{100} \\
\hline \multicolumn{2}{|c|}{ Skor Maksimum Kelompok } & \multicolumn{2}{|l|}{3200} & \multicolumn{2}{|l|}{3200} & \multicolumn{2}{|l|}{3200} \\
\hline
\end{tabular}


Berdasarkan Tabel 1, pada pembinaan untuk siklus I yang dilakukan oleh pengawas sekolah melalui supervisi klinis diperoleh nilai rata-rata peningkatan kinerja guru adalah $70,00 \%$. Hasil tersebut menunjukkan bahwa pada siklus pertama secara kelompok guru bina mata pelajaran kimia belum meningkat kinerjanya, karena yang memperoleh nilai $\geq 75$ hanya sebesar $40,63 \%$ lebih kecil dari persentase ketuntasan yang dikehendaki yaitu sebesar $85 \%$. Hal ini disebabkan karena banyak guru kurang fokus dalam mengajar dan terdapat beberapa guru baru diangkat/dilantik menjadi guru merasa baru dengan tugas tersebut.

Dalam pelaksanaan kegiatan pembinaan diperoleh informasi dari hasil pengamatan sebagai berikut: 1) pengawas masih kurang teliti dalam melakukan pembinaan di sekolah, 2) pengawas masih kurang baik dalam pemanfaat waktu, dan 3) pengawas Sekolah masih kurang konsentrasi dalam melakukan pembinaan,karena ada trugas lain yang harus dikerjakan.

Pelaksanaan kegiatan pembinaan pada siklus I ini masih terdapat kekurangan, sehingga perlu adanya revisi untuk dilakukan pada siklus berikutnya: 1) Pengawas perlu lebih terampil dalam memotivasi guru dan lebih jelas dalam menyampaikan tujuan pembinaan. Di mana kepala sekolah diajak untuk terlibat langsung dalam setiap kegiatan yang dilakukan. 2) Pengawas perlu mendistribusikan waktu secara baik dengan menambahkan informasi-informasi yang dirasa perlu dan memberi catatan, 3) Pengawas harus lebih terampil dan bersemangat dalam memotivasi guru sehingga kinerjanya lebih meningkat.

Pada siklus II, diperoleh nilai rata-rata peningkatan kinerja guru dalam melaksanakan Pembelajaran Yang Efektif adalah 77,44\% dan peningkatan kinerja guru mencapai $71,88 \%$ atau ada 23 orang dari 32 orang guru yang sudah tuntas dalam meningkatkan Kompetensinya. Hasil ini menunjukkan bahwa pada siklus II ini peningkatan kinerja guru telah mengalami peningkatan sedikit lebih baik dari siklus I. Adanya peningkatan kinerja guru ini karena setelah pengawas telah menginformasikan bahwa setiap akhir pembinaan diadakan penilaian sehingga pada pertemuan berikutnya guru lebih termotivasi untuk meningkatkan kinerjanya dalam melaksanakan pembelajaran yang efektif. Selain itu kepala sekolah juga sudah mulai mengerti apa yang dimaksudkan dan diinginkan oleh pengawas dalam melakukan supervisi klinis.

Dalam pelaksanaan pembinaan diperoleh informasi dari hasil pengamatan sebagai berikut: 1) Memotivasi guru, 2) Membimbing guru dalam menyusun rencana kerja sekolah merumuskan kesimpulan/menemukan konsep, dan 3) Pengelolaan waktu. Pelaksanaan pembinaan pada siklus II ini masih terdapat kekurangan-kekurangan. Maka perlu adanya revisi untuk dilaksanakan pada siklus III antara lain: 1) Pengawas dalam memberikan pembinaan kepada guru hendaknya dapat membuat guru termotivasi dalam membuat program dan rencana sekolah. 2) Pengawas harus lebih dekat dengan guru sehingga tidak ada perasaan takut/malu dalam diri guru terutama dalam bertanya tentang masalah yang dihadapi oleh sekolah. 3) Pengawas harus lebih sabar dalam melakukan pembinan kepada guru terutama dalam merumuskan kesimpulan / menemukan konsep. 4) Pengawas harus mendistribusikan waktu secara baik sehingga kegiatan pembinaan dapat berjalan efektif sesuai dengan yang diharapkan.

Pada Siklus III, diperoleh nilai rata-rata tes formatif sebesar $82,84 \%$ dan 32 guru secara keseluruhan sudah mencapai ketuntasan dalam meningkatkan kinerjanya dalam melaksanakan pembelajaran yang efektif. Maka secara kelompok ketuntasan telah mencapai $100 \%$ (termasuk kategori tuntas ). Hasil pada siklus III ini mengalami peningkatan lebih baik dari siklus II. Adanya peningkatan hasil pembinaan pada siklus III ini dipengaruhi oleh adanya peningkatan Kompetensi pengawas dalam menerapkan pembinaan kepengawasan melalui supervisi klinis sehingga guru menjadi lebih memahami tugasnya (peran dan fungsinya) sehingga dapat meningkatkan kinerjanya. Di samping itu ketuntasan ini juga dipengaruhi oleh kerja sama dari guru dengan pengawas dalam merencanakan program kerja sekolahnya masing masing.

Pada tahap ini dikaji apa yang telah terlaksana dengan baik maupun yang masih kurang baik dalam proses pembinaan melalui supervisi klinis. Dari data-data yang telah diperoleh dapat duraikan sebagai berikut: 1) Selama proses pembinaan pengawas telah melaksanakan semua pembinaan dengan baik. Meskipun ada beberapa aspek yang belum sempurna, tetapi persentase pelaksanaannya untuk masing-masing aspek cukup besar. 2) Berdasarkan data hasil pengamatan 
diketahui bahwa kepala sekolah aktif selama proses pembinaan berlangsung. 3) \Kekurangan pada siklus-siklus sebelumnya sudah mengalami perbaikan dan peningkatan sehingga menjadi lebih baik. 4) Hasil pembinaan guru oleh pengawas melalui supervisi klinis pada siklus III mencapai ketuntasan.

Pada siklus III pengawas telah melaksanakan pembinaan dengan baik dan dilihat dari peningkatan Kompetensi guru pelaksanaan pembinaan sudah berjalan dengan baik. Maka tidak diperlukan revisi terlalu banyak, tetapi yang perlu diperhatikan untuk tindakan selanjutnya adalah memaksimalkan dan mempertahankan apa yang telah ada dengan tujuan agar pada pelaksanaan pembinaan selanjutnya baik melalui supervisi klinis dapat meningkatkan kinerja guru dalam melaksanakan pembelajaran yang efektif sehingga tujuan pembinaan sebagai upaya meningkatkan mutu pendidikan dapat tercapai.

Melalui hasil penelitian ini menunjukkan bahwa pembinaan melalui Supervisi klinis memiliki dampak positif dalam meningkatkan kinerja guru dalam melaksanakan Pembelajaran Yang Efektif, hal ini dapat dilihat dari semakin mantapnya pemahaman kepala sekolah terhadap pembinaan yang disampaikan pengawas (Kinerja guru meningkat dari siklus I, II, dan III ) yaitu masingmasing $70,00 \% ; 77,44 \% ; 82,84 \%$. Pada siklus III Kompetensi guru dalam melaksanakan Pembelajaran Yang Efektif secara kelompok dikatakan tuntas.

Berdasarkan analisis data, diperoleh aktivitas guru dalam meningkatkan kinerjanya dalam setiap siklus mengalami peningkatan. Hal ini berdampak positif terhadap kinerja guru yaitu dapat ditunjukkan dengan meningkatnya nilai rata-rata guru pada setiap siklus yang terus mengalami peningkatan. Untuk aktivitas pengawas, paling dominan yang diperoleh dalam kegiatan Supervisi klinis adalah bekerja dengan menggunakan alat/media, mendengarkan/memperhatikan penjelasan pengawas, dan diskusi antar guru dan pengawas. Jadi dapat dikatakan bahwa aktivitas guru dapat dikategorikan aktif. Sedangkan untuk aktivitas pengawas selama pembinaan telah melaksanakan langkah-langkah metode pembinaan melalui Supervisi klinis dengan baik. Hal ini terlihat dari aktivitas guru yang muncul di antaranya aktivitas membuat dan merencanakan program sekolah, melaksanakan, memberi umpan balik/evaluasi/tanya jawab di mana prosentase untuk aktivitas di atas cukup besar.

Berdasarkan hasil penelitian, peningkatan kinerja guru melalui pembinaan Supervisi klinis hasilnya sangat baik. Hal itu tampak pada pertemuan pertama dari 32 orang guru yang ada pada saat penelitian ini dilakukan nilai rata rata mencapai ; 61,94\% meningkat menjadi $71,28 \%$ dan pada siklus 3 meningkat menjadi $80,83 \%$. Selain itu, kinerja pengawas melalui supervisi klinis efektif diterapkan dalam upaya meningkatkan kinerja guru, yang berarti proses pembinaan pengawas lebih berhasil dan dapat meningkatkan kinerja guru dalam melaksanakan pembelajaran yang efektif khususnya guru binaan mata pelajaran kimia di SMA Lombok Tengah Tahun Pelajaran 2018-2019, oleh karena itu diharapkan kepada para pengawas dapat melaksanakan pembinaan melalui supervisi klinis secara berkelanjutan.

\section{Kesimpulan}

Berdasarkan analisis hasil penelitian dan pembahasan disimpulkan bahwa: 1) Pembinaan Pengawas dalam upaya meningkatkan kinerja guru-guru binaan mata pelajaran kimia dalam melaksanakan Pembelajaran Yang Efektif melalui Supervisi klinis menunjukan peningkatan pada setiap siklus. 2) Aktivitas dalam kegiatan pembinaan bahwa guru-guru binaan mata pelajaran kimia dapat meningkatkan kinerja pada proses pelaksanaan Pembelajaran Yang Efektif dengan baik dalam setiap aspek. 3) Peningkatan kinerja guru dalam melaksanakan peran dan fungsinya oleh pengawas melalui Supervisi klinis ini menunjukan peningkatan pada tiap siklus. 4) Aktivitas guru menunjukkan bahwa kegiatan pembinaan Supervisi klinis bermanfaat dan dapat membantu guru untuk lebih mudah memahami konsep peran dan fungsi guru sehingga kinerja guru dapat meningkat.

\section{Saran}

Berdasarkan hasil penelitian yang telah dilkukan, maka dapat dikemukakan saran: 1) Pembinaan pengawas melalui Supervisi klinis dalam upaya meningkatkan kinerja guru dalam melaksanakan Pembelajaran Yang Efektif diperlukan perhatian penuh dan disiplin yang tinggi 
pada setiap langkah pembinaan, dan perencanaan yang matang misalnya dalam pengalokasian waktu dan pemilihan konsep yang sesuai. 2) Kepada guru diharapkan selalu mengikuti perkembangan jaman, terutama dengan membaca hasil karya para akhli sehingga tidak ketinggalan dengan daerah lain, dalam meningkatkan mutu pendidikan, sebagai tanggung jawab bersama memajukan pendidikan. 3) Penelitian ini masih perlu dikembangkan dengan fokus alat ukur keberhasilan yang lebih reliabel agar dapat menggambarkan peningkatan kinerja guru dengan baik sehingga mutu pendidikan dapat ditingkatkan.

\section{Daftar Pustaka}

Ace. S \& Tilaar, H.A.R. 1994. Analisis Kebijakan Pendidikan. Bandung: Remaja Rosdakarya.

Amani, L., Dantes, N. \& Lasmawan, W. 2013. Implementasi Supervisi Klinis Dalam Rangka Meningkatkan Kemampuan Guru Mengelola Proses Pembelajaran Pada Guru SD se-Gugus VII Kecamatan Sawan. e-Journal Program Pascasarjana Universitas Pendidikan Ganesha, 3 (1).

Arikunto, S. 2004. Dasar-Dasar Supervisi. Jakarta: Rineka Cipta.

Danim, S. 2002. Inovasi Pendidikan Dalam Upaya Peningkatan Profesionalisme Tenaga Kependidikan. Bandung: Pustaka.

Jerry, M. 2013. Supervisi Klinis Teori \& Pengukurannya (Analisis di Bidang Pendidikan). Bandung: Alfabeta.

Kemmis, S \& Mc Taggart, R. 1992.The Action Research Planner. Australia: Deakin University Press. 